\title{
Geophysical and hydrocarbon prospect evaluation of Nukhul Formation at Rabeh East oil field, Southern Gulf of Suez Basin, Egypt
}

\author{
Mohammad Abdelfattah Sarhan ${ }^{1,2}$ (D)
}

Received: 10 March 2021 / Accepted: 30 May 2021 / Published online: 6 June 2021

(c) The Author(s) 2021

\begin{abstract}
Nukhul Formation is one of the primary oil reservoirs in the Gulf of Suez Basin. Rabeh East is an oil producer field located at the southern border of the Gulf of Suez. The present work deals with the geophysical investigation of Nukhul Formation in Rabeh East field using seismic lines and well log data of four wells, namely RE-8, RE-22, RE-25 and Nageh-1. The interpreted seismic profiles display that the RE-8 Well is the only well drilled within the up-thrown side of a significant horst fault block bounded by two normal faults. However, the other wells penetrated the downthrown side. The qualitative interpretation of the well logging data for RE-8 Well delineated two intervals have good petrophysical parameters and ability to store and produce oil. These zones locate between depths 5411.5 and $5424 \mathrm{ft}$ (zone I) and between 5451 and $5459.5 \mathrm{ft}$ (zone II). The calculated petrophysical parameters for zone I display water saturation (22-44\%), shale volume (10-23\%), total porosity (18-23\%), effective porosity (12-20\%) and bulk volume of water (0.04-0.06). Zone II exhibits water saturation (13-45\%), shale volume (10-30\%), total porosity (18-24\%), effective porosity (11-20\%) and bulk volume of water $(0.03-0.05)$. This analysis reflects excellent petrophysical characteristics for the sandstones of Nukhul Formation in Rabeh East oil field for producing oil if the wells drilled in a suitable structural closure.
\end{abstract}

Keywords Geophysical evaluation · Well logging $\cdot$ Seismic interpretation $\cdot$ Nukhul Formation $\cdot$ Rabeh East oil field $\cdot$ Gulf of Suez Basin

\section{Introduction}

The Gulf of Suez is one of the oldest oil provinces all over the world. The Gulf of Suez Basin extends around $325 \mathrm{~km}$ from the north-western end of the Red Sea to the north direction between Sinai in the east and Eastern Desert in the west (Patton et al. 1994; El Nady et al. 2016) occupying an area about $19,000 \mathrm{~km}^{2}$. Its width differs from about $50 \mathrm{~km}$ in the north to around $90 \mathrm{~km}$ in its southern end at the Red Sea (Bosworth and McClay 2001). The Gulf of Suez provenance is considered the greatest productive oil rift basin in Africa and the Middle East since it comprises more than 80 oil fields producing from the Precambrian to Quaternary (Schlumberger 1995; El Nady et al. 2015; Moustafa

Mohammad Abdelfattah Sarhan

msarhan@du.edu.eg; msarhan12@yahoo.com

1 Geology Department, Faculty of Science, Damietta University, New Damietta City 34517, Egypt

2 Center of Space Research and Applications (CSRA), Damietta University, New Damietta City, Egypt and Khalil 2020; Alsharhan 2003; Radwan and Sen 2021; Radwan 2021a, b; Radwan et al. 2021a, b).

Several structural and sedimentological studies on the evolution of the Gulf of Suez rift have been done due to the existence of well-exposed and well-dated syn-rift strata in addition to the large amounts of exploration data on this region (Winn et al. 2001; Radwan et al. 2020, 2021c; Radwan 2021b).

The structural fault blocks initiated at the rifting time represent the main hydrocarbon traps and control the petroleum accumulation in the Gulf of Suez oil fields (Chowdhary and Taha 1987; Sultan 2002).

The syn-rift Miocene sandstones hold approximately $60 \%$ of oil reserves in the Gulf of Suez Basin, and the residual is mostly present in the Nubia Formation (Peijs et al. 2012).

Nukhul Formation is considered the main heavy oil producer from the Early Miocene at the Gulf of Suez region because of its highly fractured nature (Temraz and Dypvik 2018). But it also represents high quality hydrocarbon reservoirs in more than fifteen oil fields at the Gulf of Suez region (Saoudi and Khalil 1984). 
The area of study situated between latitudes $27^{\circ} 9^{\prime} 36.3^{\prime \prime}$ $\mathrm{N}$ to $27^{\circ} 17^{\prime} 0.7^{\prime \prime} \mathrm{N}$ and longitudes $33^{\circ} 39^{\prime} 16.8^{\prime \prime} \mathrm{E}$ to $33^{\circ}$ $47^{\prime} 56.1^{\prime \prime} \mathrm{E}$ at the southern portion of the Gulf of Suez area (Fig. 1). Rabeh East field holds several drilled wells. The sandstones of Nubia and Matulla formations display good petrophysical parameters for oil production at Rabeh East oil field. They exhibit thick net pays, high effective porosity, low shale volume and low water saturation (Abd El Gawad et al. 2016; Sarhan and Basal 2019). Moreover, the carbonate of Rudeis Formation represents one of the oil-bearing reservoirs in Rabeh East Field (Sarhan 2020).

As a result, the current work aims to conduct a geophysical assessment of the Nukhul Formation in order to add new reserves to the existing reservoirs in Rabeh East field. The interpretation of seismic and well log data was used to conduct this geophysical assessment.

\section{Geologic setting}

The Gulf of Suez provenance is a rift formed in the Early Miocene due to the divergent movement between the African plate and the Arabian plate. This movement created series of normal faults particularly NW-SE to NNW-SSE trending (Patton et al. 1994; Bosworth et al. 2005). These faults transferred to the north-west and affected the Late Miocene sequence at the Nile Delta area (Sarhan et al. 2014). The Gulf of Suez district is complicated in its structural and depositional patterns due to the superimposing of the syn-rift faults over the pre-rift structures (Abul Karamat and Meshref 2002).

The faulted blocks at the Gulf of Suez rift bounded primarily by NW normal faults which are connected to each other by NNE-, NE- and WNW-oriented faults (Abd-Allah et al. 2014).

The syn-rift Miocene rocks in the Gulf of Suez area change laterally from clastics (conglomerate and sandstone) to more deeper sediments (sandstone, marl, shale, limestone and evaporates) towards the rift axis (Bosworth and McClay 2001). Tilting of the pre-rift blocks made the Miocene rocks resting on the different pre-rift units and vary in lithologies and thicknesses (Abd-Allah et al. 2014).

The stratigraphic section based on the mud $\log s$ of the examined wells in Rabeh East Field starts with the pre-Cretaceous Nubia Formation which overlain by the Cretaceous Matulla and Sudr formations. This section is topped by the Paleocene Esna Shale Formation and then the Eocene Thebes Formation. However, the Miocene rock units includes from base to top: Nukhul Formation, Rudeis Formation, Kareem Formation, Belayim Formation, South Gharib Formation and Zeit Formation (Fig. 2). Based on the available wells, Nukhul Formation is composed of mainly of sandstones and shale beds intercalated with limestones and evaporated interbeds (Fig. 3).

The lower clastic interval of the Nukhul Formation deposited in shallow marine conditions (Schutz 1994; Abd El Gawad et al. 2016) and partially filling submarine gullies that transported debris from uplifted areas (Temraz and Dypvik 2018). However, some portions of Nukhul
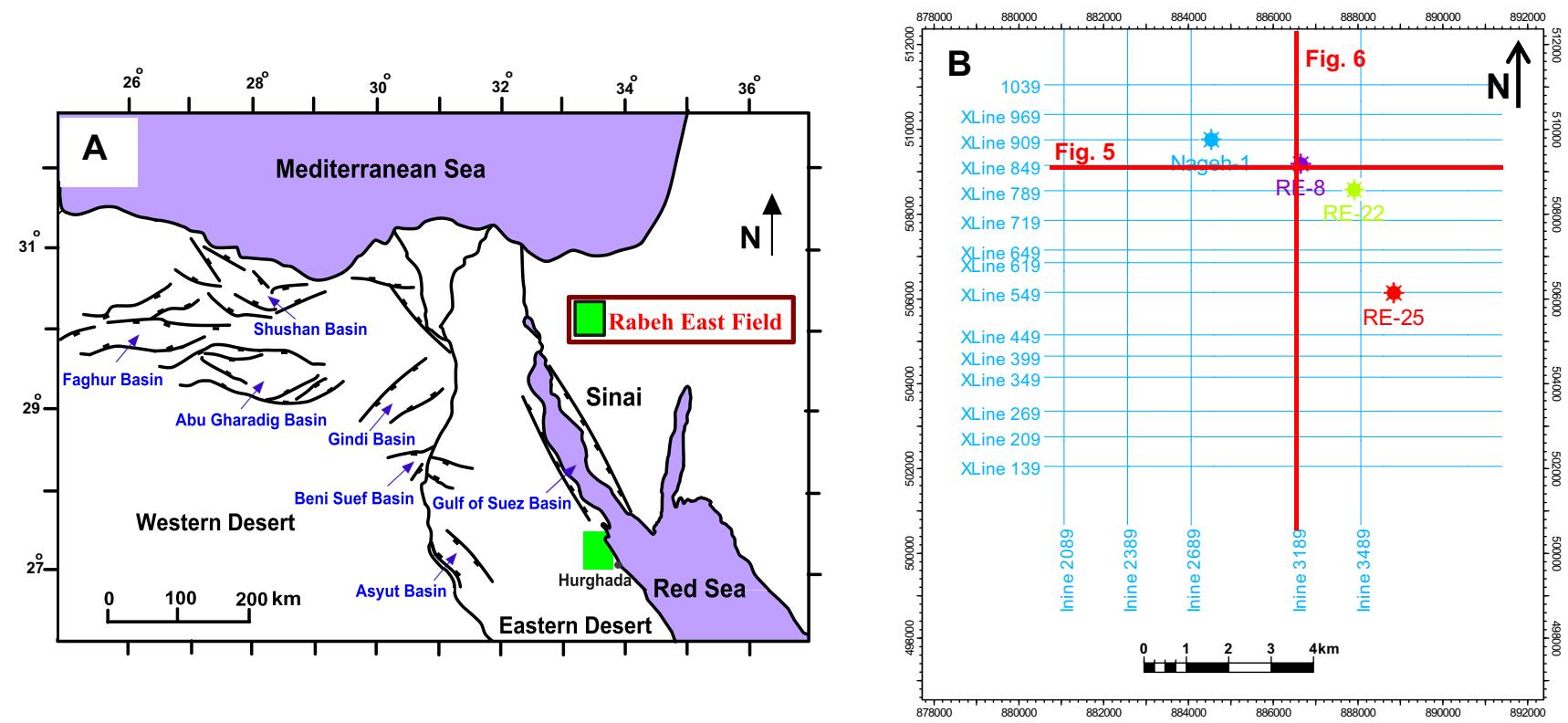

Fig. 1 a Regional map represents the location of Rabeh East field at the southern margin of Gulf of Suez Basin. b Study area with seismic profiles and well locations 


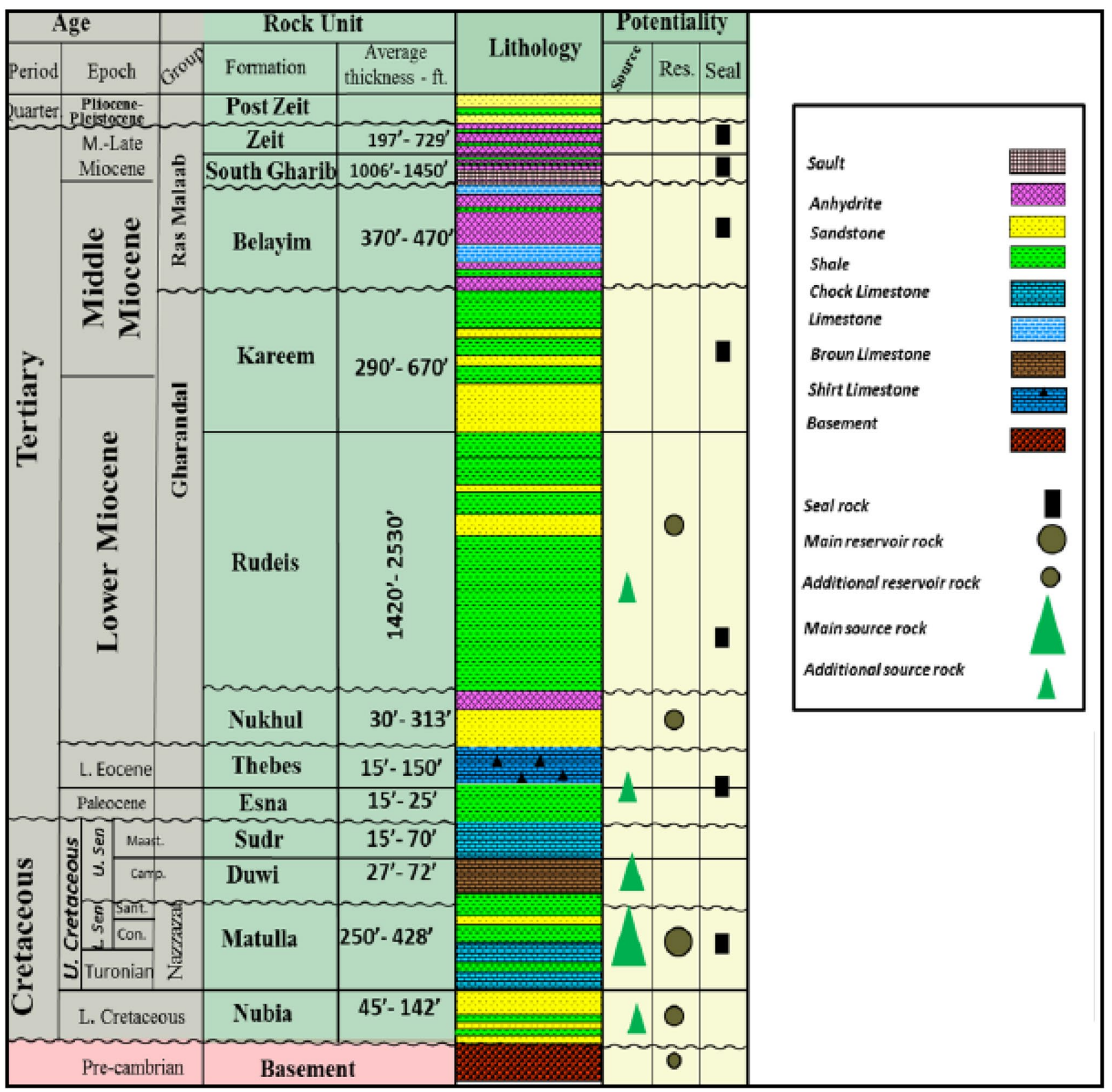

Fig. 2 Lithostratigraphic units at West Hurghada district including Rabeh East field (after Abd El Hafez et al. 2016)

Formation possibly deposited in deep marine environment (McClay et al. 1998).

The Early Miocene Nukhul Formation is the first syn-rift rock unit in the in the Gulf of Suez area (Temraz and Dypvik 2018). Its type section located at Wadi Nukhul in the central eastern portion of the Gulf of Suez. It is generally composed essentially of conglomerates, sandstones, shale and marl, limestones and evaporites (Abd El Hafez et al. 2016; Temraz and Dypvik 2018). In outcrops at the west of the Hurghada area, the lowermost syn-rift conglomerates referred as the Abu Gerfan Formation (Bosworth and McClay 2001).

\section{Data and methodology}

The existing geophysical data in this study comprise twenty seismic sections covering the study area of Rabeh East oil field at the southern margin of the Gulf of Suez Basin (Fig. 1a). These seismic profiles have been tied to four wells drilled in the study area: Rabeh East-25 (RE-25), Rabeh East-22 (RE-22), Rabeh East-8 (RE-8) and Nageh-1 wells as shown in Fig. 1b. The wireline logs for the four wells are also accessible including calliper, gamma ray, sonic, microspherical resistivity, deep resistivity, density, neutron 


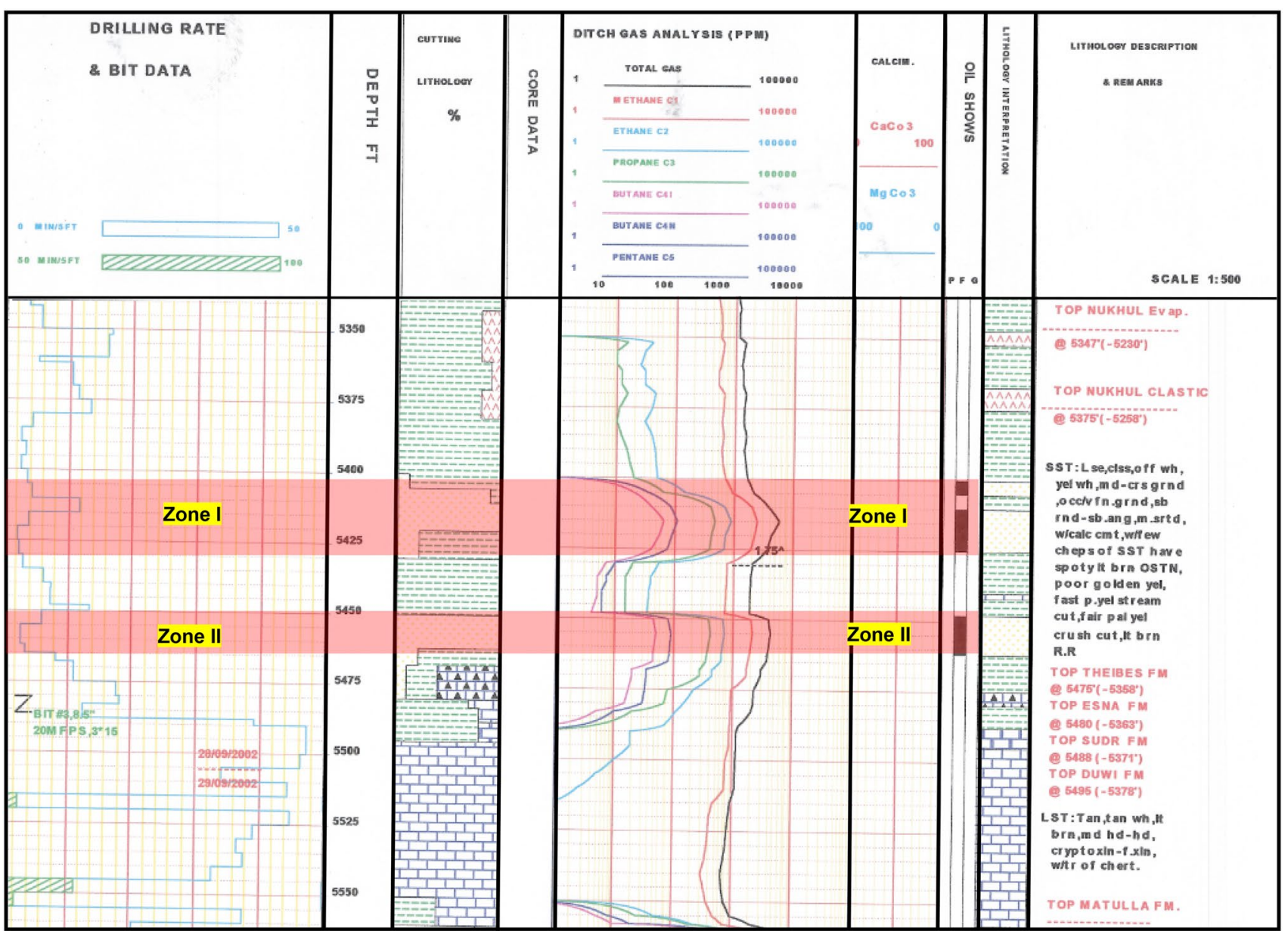

Fig. 3 Mud log displays the Nukhul Formation in RE-8 Well. Note that the red rectangles outline the most promising hydrocarbon-bearing zones between depths 5411.5 and $5424 \mathrm{ft}$ (zone I) and between 5451 and $5459.5 \mathrm{ft}$ (zone II)

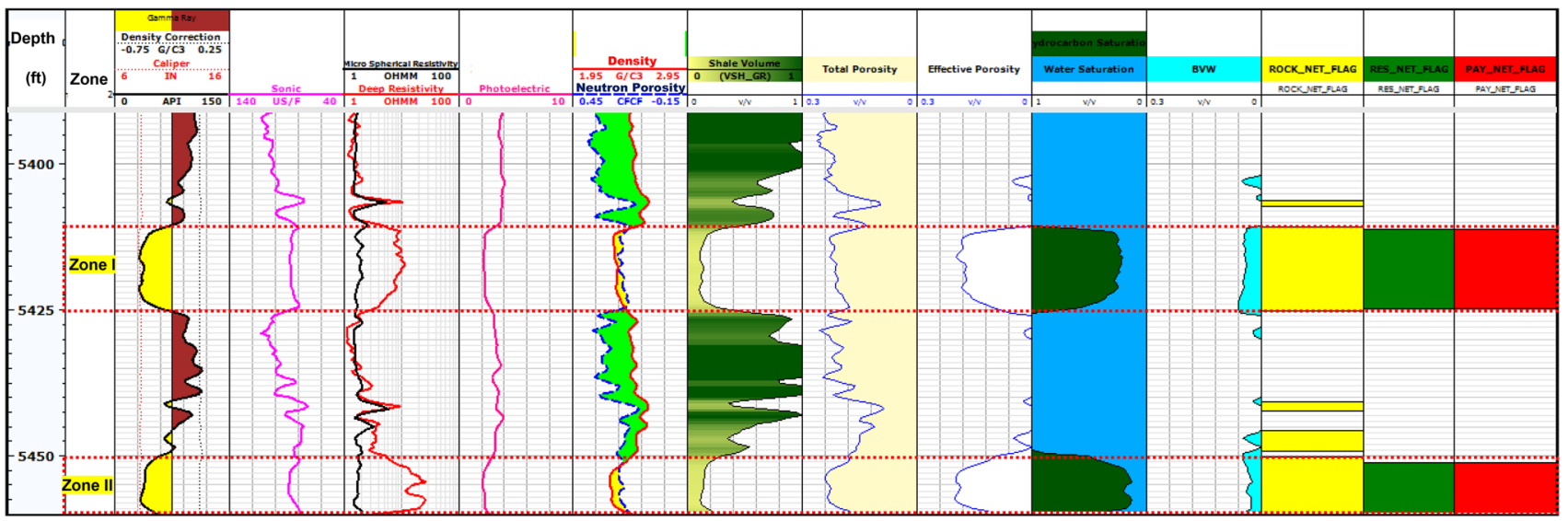

Fig. 4 Petrophysical data with interpretation for the Nukhul Formation in RE-8 Well representing the highly promising characteristics for oil production in zone I and zone II (outlined by red rectangles) 


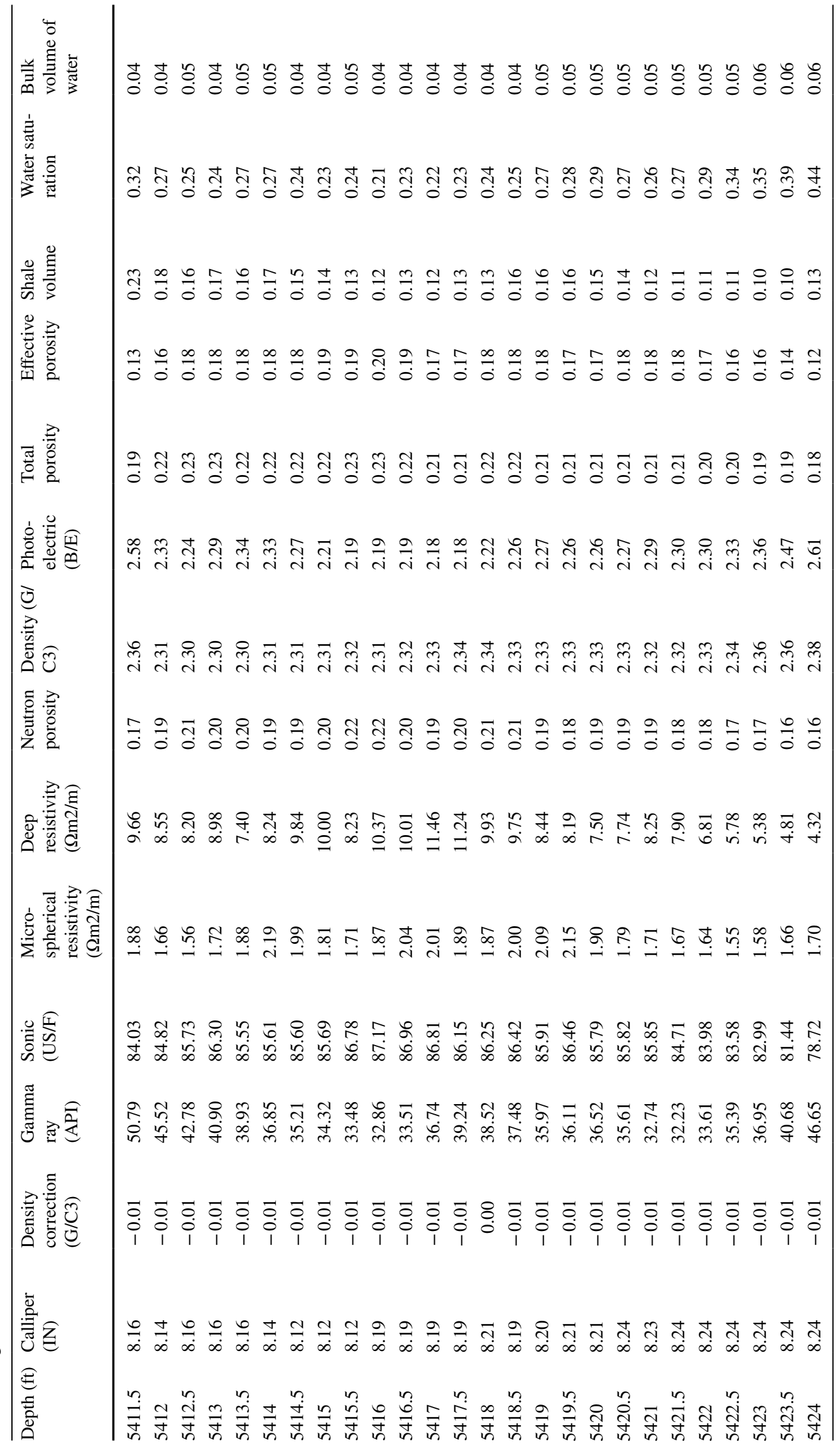




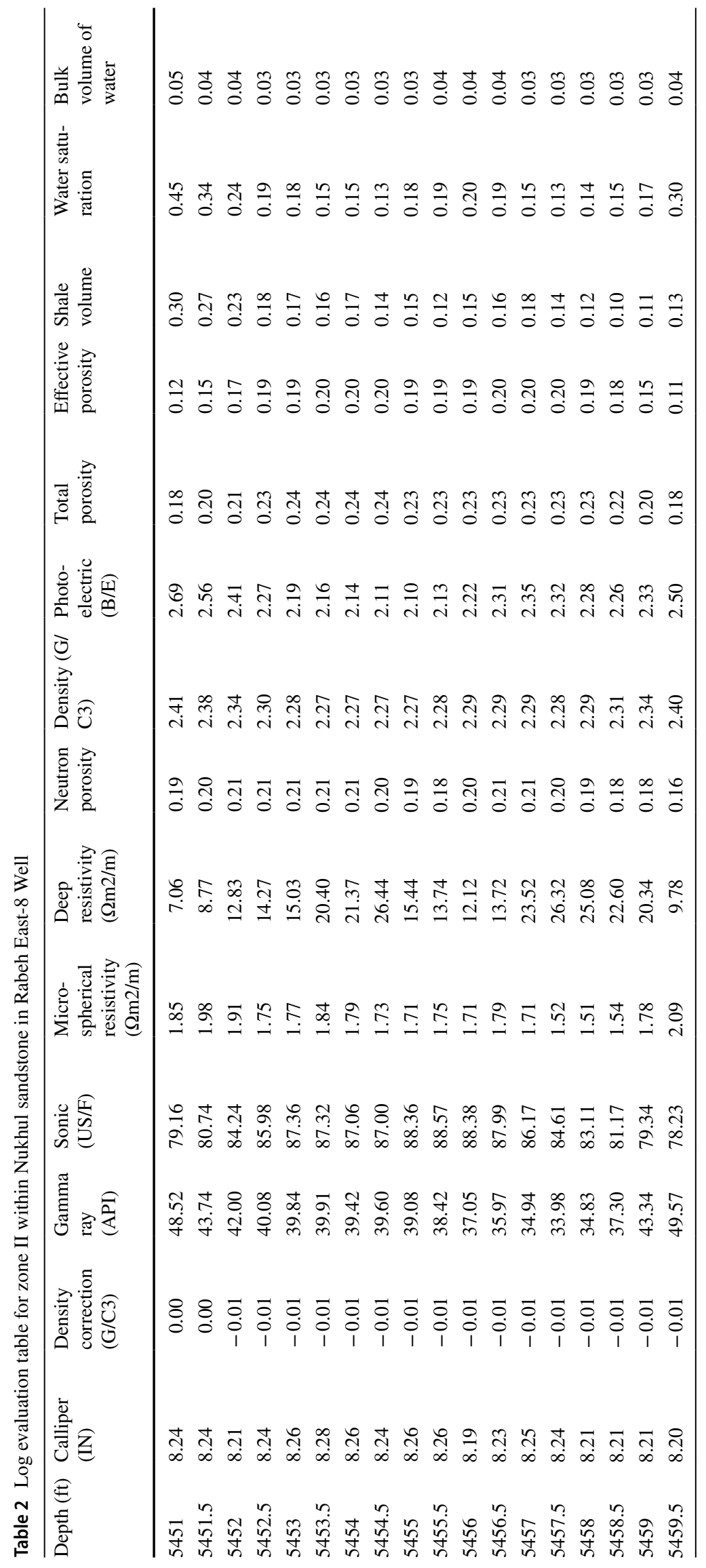


porosity and photoelectric logs as presented in Fig. 4 and Tables 1 and 2. The mud logs for the four wells are also available. Each mud log comprises the drilling rate and lithology in addition to the ditch gas analysis and the oil shows which are helpful in referring to the hydrocarbonbearing zones (Fig. 3).

The performed techniques in the current work have been done through mud log, seismic and well log appraisal for Nukhul Formation in Rabeh East field. At first, mud logs for the four wells have been treated qualitatively for distinguishing the possible hydrocarbon-bearing zones within Nukhul Formation. The seismic sections have been also inspected to examine the locations of the four drilled wells relative to the interpreted normal faults affected the Rabeh East oil field. The well log data have been examined to calculate the most important petrophysical parameters for the zones of interest using Techlog Software. These parameters include shale volume $\left(V_{\text {Shale }}\right)$, total porosity $\left(\Phi_{\mathrm{T}}\right)$, effective porosity $\left(\Phi_{\mathrm{E}}\right)$, water saturation $\left(S_{\mathrm{w}}\right)$ and bulk volume of water (BVW).

\section{Shale volume $\left(\mathrm{V}_{\mathrm{sh}}\right)$}

The amount of shale in the inspected intervals has been determined based on gamma ray log as a linear response using the equation of Asquith and Gibson (1982):

$V_{\mathrm{sh}}=\left(\mathrm{GR}-\mathrm{GR}_{\min }\right) /\left(\mathrm{GR}_{\max }-\mathrm{GR}_{\min }\right)$

where $V_{\mathrm{sh}}$ is the shale volume; GR is the gamma ray reading value; $\mathrm{gr}_{\min }$ is the lowest gamma ray value; and $\mathrm{gr}_{\max }$ is the maximum gamma ray value.

\section{Total porosity $\left(\phi_{T}\right)$}

Total porosity indicates the total volume of voids in a rock even primary or secondary in source. $\phi_{\mathrm{T}}$ has been calculated from the neutron-density logs using the following formula after Asquith and Gibson (1982):

$\Phi_{\mathrm{T}}=\left(\Phi_{\mathrm{N}}+\Phi_{\mathrm{D}}\right) / 2$

where $\Phi_{\mathrm{T}}$ is the total porosity; $\Phi_{\mathrm{N}}$ is the neutron porosity; and $\Phi_{\mathrm{D}}$ is the density porosity.

The neutron porosity $\left(\Phi_{\mathrm{N}}\right)$ is the reading of the neutron $\log$ which measures the hydrogen concentration in a reservoir. In clean (i.e. shale-free) reservoir where the porosity is filled with oil or water, the neutron log measures liquid filled porosity $\left(\Phi_{\mathrm{N}}\right)$. However, the density porosity $\left(\Phi_{\mathrm{D}}\right)$ can be determined using the following formula:

$\Phi_{D}=\left(\rho_{\mathrm{ma}}-\rho_{b}\right) /\left(\rho_{\mathrm{ma}}-\rho_{f}\right)$

where $\Phi_{\mathrm{D}}=$ density derived porosity; $\rho_{\mathrm{ma}}=$ matrix density; $\rho_{\mathrm{b}}=$ formation bulk density (the log reading) which is a function of matrix density, porosity and density of the fluid in the pores (freshwater mud, saltwater mud or hydrocarbons); and $\rho_{\text {fl }}=$ fluid density.

\section{Effective porosity $\left(\phi_{\mathrm{e}}\right)$}

The effective porosity measures only the interconnected voids within which fluids can be transmitted (Asquith and Gibson 1982). It has been determined by the following equation:

$\phi_{\mathrm{e}}=\phi_{\mathrm{T}} \times\left(1-V_{\mathrm{sh}}\right)$

where; $\phi_{\mathrm{e}}$ is the effective porosity; $\phi_{\mathrm{T}}$ is the total porosity; and $V_{\mathrm{sh}}$ is the shale volume.

\section{Water saturation $\left(S_{w}\right)$}

The Indonesia model (Poupon and Leveaux 1971) has been applied to calculate water saturation for the examined zones. This model used in case of shaly reservoir as in the current case since the shale volume varies between 10 and $30 \%$. In this model, water saturation can be calculated from the following equation:

$s_{\mathrm{w}}=\left\{\left[\left(\frac{V_{\mathrm{sh}}^{2-V_{\mathrm{sh}}}}{R_{\mathrm{sh}}}\right)^{1 / 2}+\left(\frac{\phi_{\mathrm{e}}^{m}}{R_{\mathrm{w}}}\right)^{1 / 2}\right]^{2} R_{\mathrm{t}}\right\}^{-1 / n}$

where $S_{\mathrm{w}}$ is the water saturation; $V_{\mathrm{sh}}$ is the shale volume; $\phi_{\mathrm{e}}$ is the effective porosity; $R_{\mathrm{sh}}$ is the shale resistivity; $R_{\mathrm{t}}$ is the deep resistivity; $R_{\mathrm{w}}$ is the connate water resistivity (set equals $0.019 \Omega \mathrm{m}^{2} / \mathrm{m}$ according to Ganoub El-Wadi Petroleum Company); $\mathrm{m}$ is the cementation exponent (set equal 2 ); $\mathrm{n}$ is the saturation exponent (set equal 2); and a is the tortuosity factor (set equal 1).

\section{Bulk volume of water (BVW)}

The bulk volume of water is an important parameter in evaluating the reservoir zones. BVW is the result of water saturation times porosity. If the calculated BVW values are low and constant in a specific zone, this zone is predictable to produce water-free hydrocarbon. It can be determined by applying the following equation (after Buckles 1965):

$\mathrm{BVW}=\phi_{\mathrm{e}} \times s_{\mathrm{w}}$

where $\phi_{\mathrm{e}}$ is the effective porosity and $S_{\mathrm{w}}$ is the water saturation. 


\section{Results and discussion}

\section{Mud logging analysis}

The qualitative explanation of the mud logs revealed that only the sandstones of Nukhul Formation at RE- 8 Well showing optimistic criteria for holding hydrocarbon. These positive signs include the high values of the ditch gas analysis in addition to the presence of oil shows opposite two zones intervals located between depths 5411.5 and $5424 \mathrm{ft}$ (zone I) and between 5451 and $5459.5 \mathrm{ft}$ (zone II) as shown in Fig. 3.

The Nukhul sandstones of the examined zones have been described in the mud log report in Fig. 3 as loose, colourless, off-white, yellow white, moderate- to course-grained, occasionally very fine-grained, sub-rounded to sub-angular, moderately sorted with calcareous cement. All of the previous characteristics reflect the good textural maturity of the entire sandstones. Moreover, these sandstones show spotty brown oil stain with fast pale yellow stream cut (Fig. 3).

\section{Seismic interpretation}

The horizon corresponds to the top of Nukhul Formation in the seismic profiles and displays that RE-8 Well drilled within a clear horst structure bounded by two normal faults. The other surroundings wells (RE-22, RE-25 and Nageh-1 wells) were drilled in the downthrown sides (i.e. lower in elevation than RE-8 Well) of the interpreted faults as displayed in Figs. 5 and 6.

Accordingly, only the suite of the wireline logs of RE-8 Well has been quantitatively assessed comprising the calculations of different petrophysical parameters essential for describing the hydrocarbon potentiality for expected reservoirs.

\section{Geophysical log evaluation}

\section{Visual log evaluation}

The visual scanning for the wireline logs of Nukhul Formation in RE-8 Well showing that the promising intervals (zone I and zone II) as shown in Fig. 4 exhibit good borehole condition where the density correction is zero (Track 1 in Fig. 4).

The two examined zones are characterized by the occurrence of small amount of shale which is evidenced by the low gamma ray curve (Track 1 in Fig. 4) with values varies between 32 and 50 API (Tables 1 and 2). The sonic log shows values ranging between 78 and $88 \mu \mathrm{s} / \mathrm{ft}$ (Track 2 in Fig. 4). The deep resistivity values varies from 4 to 26
$\Omega \mathrm{m}^{2} / \mathrm{m}$ with displaying a significant separation between the deep resistivity and microspherical resistivity as displayed in Track 3 in Fig. 4. The photoelectric curve displays value around $2 \mathrm{~b} / \mathrm{e}$ reflecting the relatively clean nature of the examined sandstone (Track 4 in Fig. 4), the neutron and density curves displaying the crossover feature reflecting the sandstone matric (Track 5 in Fig. 4).

Therefore, the visual examination based on well logging data declared that the two zones intervals display the supreme positive criteria for the presence of hydrocarbon in RE-8 well. These optimistic criteria comprise the variation in the resistivity curves since the deep resistivity exceeds the microspherical resistivity. Also, porosity logs (i.e. density and neutron porosity) exhibit high porosity values that range between 18 and $24 \%$. The neutron-density cross-plot of Schlumberger (1972) for zone I and zone II within Nukhul Formation in Rabeh East-8 Well shows clearly these high porosity values (Fig. 7). Moreover, both intervals have low shale contents since the calculated volume of shale in these zones varies only between 10 and 30\% (Tables 1 and 2).

Figures 8, 9,10,11 show cross-plots that display the significant difference between the examined zones (I and II) and the rest of Nukhul Formation in RE-8 Well confirming the special characteristics of these two intervals within the sandstones of Nukhul Formation.

\section{Quantitative log evaluation}

Additional mathematical calculations have been performed for zone I and zone II by calculating the most important petrophysical parameters used in evaluating hydrocarbon reservoirs including the effective porosity, the water saturation and the bulk volume of water as displayed in Tables ( 1 and 2).

In zone I, shale volume varies between 0.10 and 0.23 , total porosity differs from 0.18 to 0.23 , the effective porosity fluctuates between 0.12 and 0.19 , and the values of water saturation fluctuates between 0.21 and 0.44 (Table 1). However, in zone II, shale volume varies between 0.10 and 0.30 , total porosity ranges among $0.18-0.24$, the effective porosity ranges between 0.11 and 0.20 , and the values of water saturation fluctuates between 0.13 and 0.45 (Table 2).

\section{Pickett plot}

Pickett plot (Pickett, 1972) has also been constructed for the studied zones in Fig. 12. This plot displays the relation between the deep resistivity $\left(R_{\mathrm{t}}\right)$ on the $\mathrm{x}$-axis and the effective porosity $\left(\Phi_{\mathrm{e}}\right)$ on the y-axis on logarithmic scales. The all plotted points representing the examined zones are clustered and located less than $S_{\mathrm{w}}=50 \%$ line representing the hydrocarbon potentiality of both zones because the hydrocarbon saturation expected to be more than $50 \%$. This result 


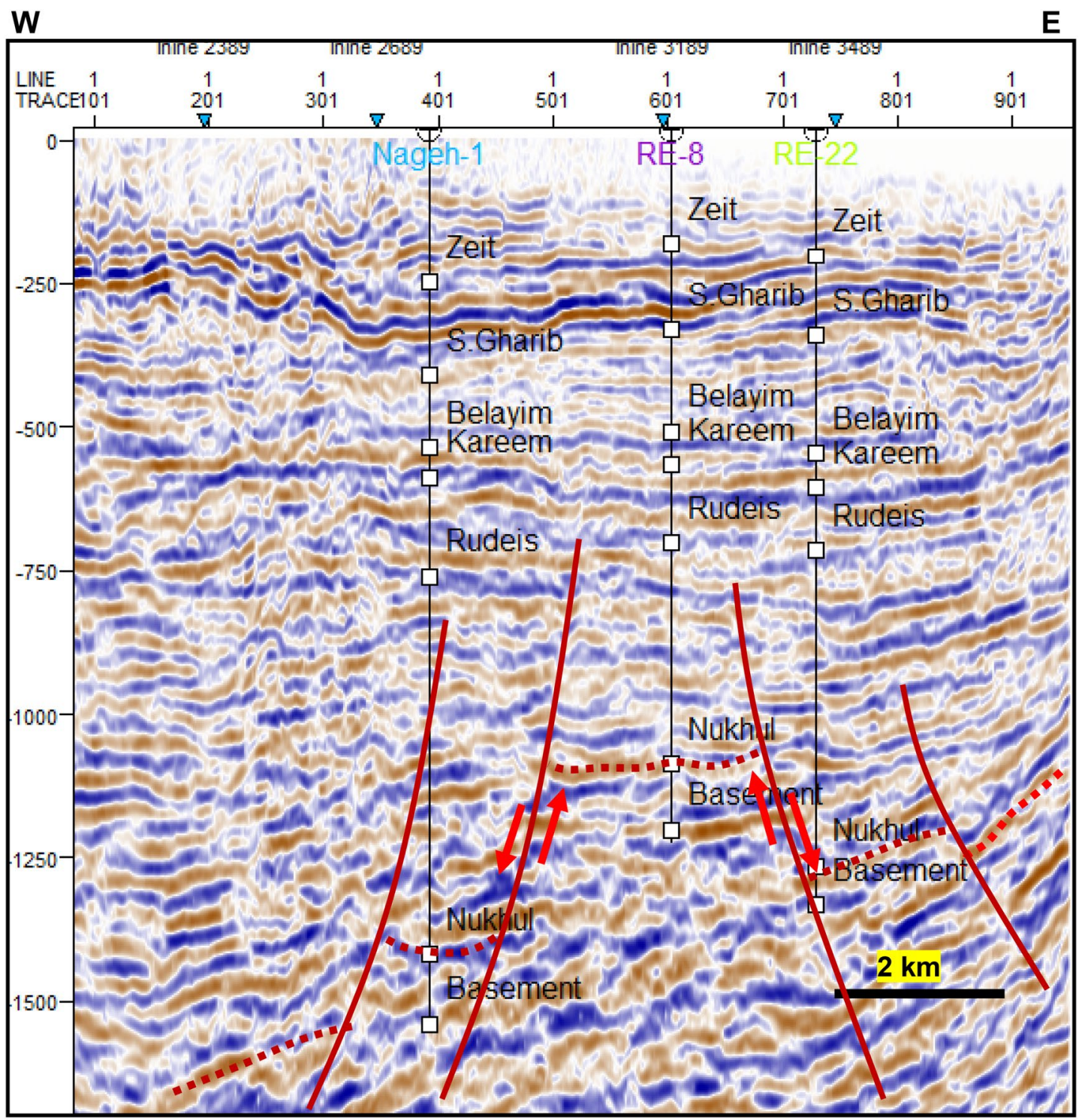

Fig. 5 Interpreted east-west seismic cross-line No. 849 displays the horst structure in the study area. Note that the top of Nukhul Formation (dotted red line) exhibits a clear raised fault block bounded by

matches the calculated water saturation values which reflects the accuracy of mathematical calculations and the importance of these zones for being oil-bearing zones.

\section{Bulk volume of water}

In zone I, the bulk volume of water is between 0.04 and 0.06 (Table 1). However, in zone II, the bulk volume of water is between 0.03 and 0.05 (Table 2).

The bulk volume of water at the irreducible case in sandstone reservoirs (i.e. expectable to yield water-free oil) depends on the grain size. If sand grains are moderate- to coarse-grained as the sand grains in the present case, the two normal faults (solid red lines) for Rabeh East-8 Well relative to the surroundings wells (Rabeh East-22 Well and Nageh-1 Well)

BVW values should vary between 0.02 and 0.035 (Asquith and Gibson 1982; Fertl and Vercellino 1978; Asquith 1985).

The bulk volume of water values for zone I and zone II within the Nukhul Formation in RE-8 Well varies between 0.03 and 0.06 (Tables 1 and 2); therefore, it is expected that they will produce oil with water. The production data for RE-8 Well confirm this result since the yield oil from Nukhul sandstones in this well equals 590 barrel of oil per day from the total production of 655 barrel per day. Accordingly, the examined sandstones produce 65 barrel of water per day (i.e. $655-590 \mathrm{barrel} /$ day). Water cut (W.C.) is a terminology that refers to the water which produces with oil in oil-producing reservoirs. So, the water cut in the examined

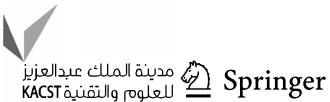




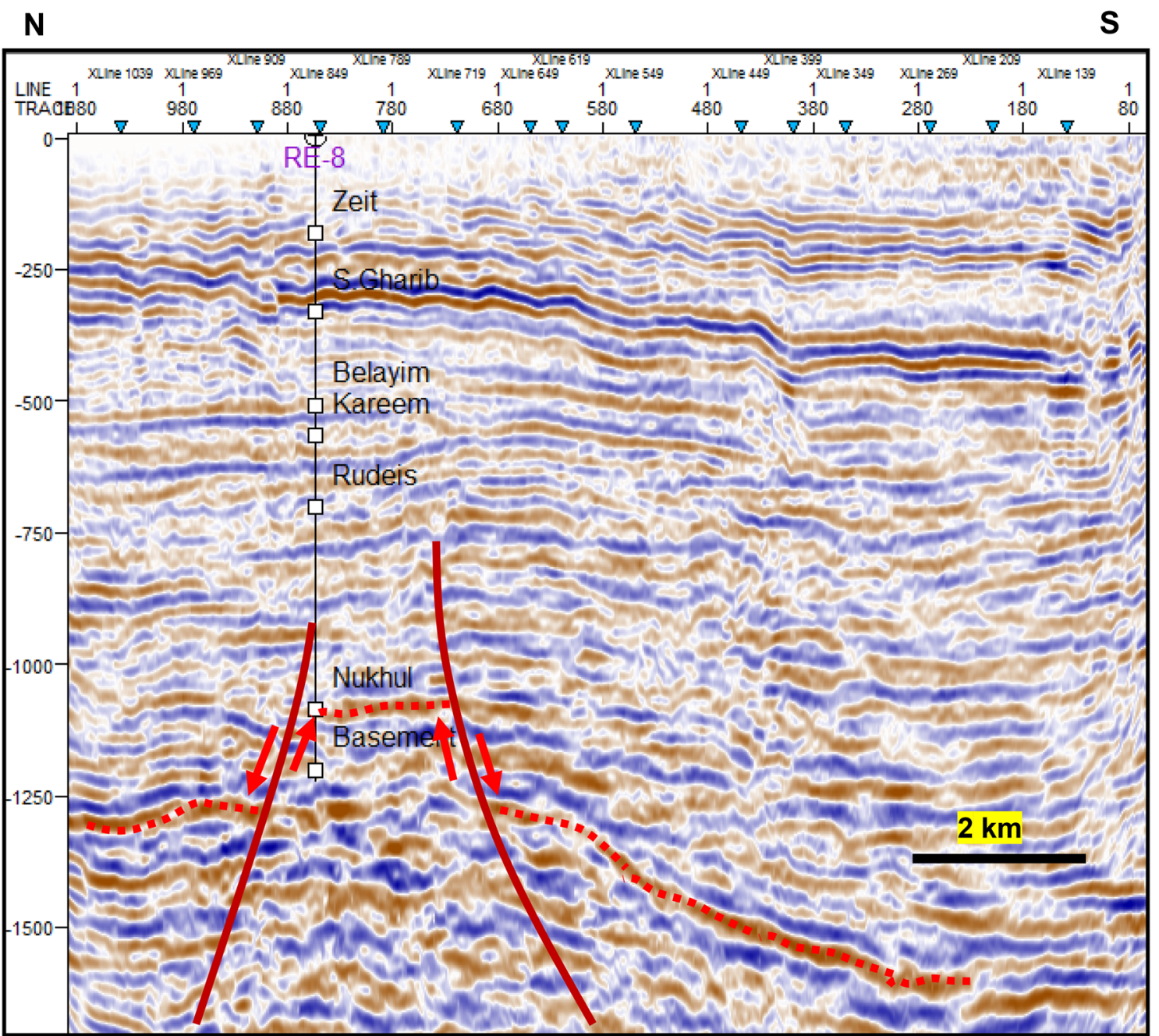

Fig. 6 Interpreted north-south seismic in line No. 3189 displays the horst structure in the study area. Note that the top of Nukhul Formation (dotted red line) exhibits a clear raised fault block bounded by two normal faults (solid red lines) for Rabeh East-8 Well

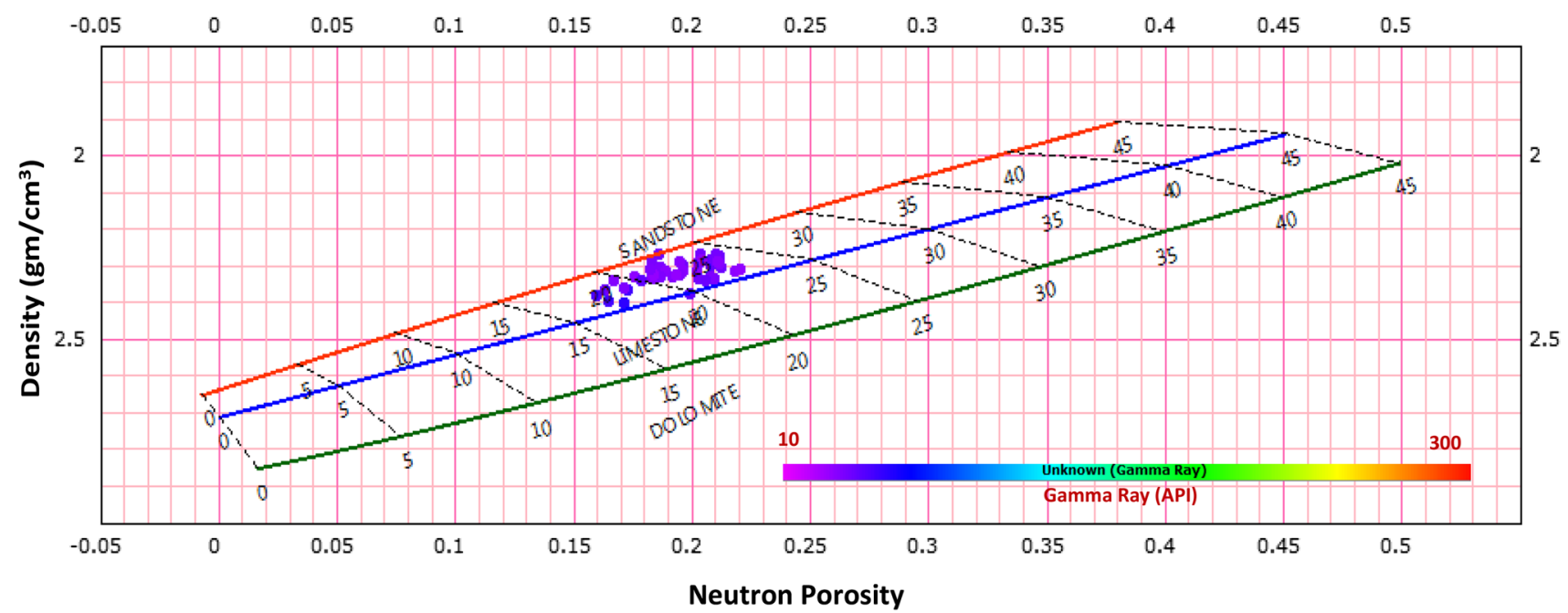

Fig. 7 Neutron-density cross-plot (after Schlumberger 1972) for zone I and zoneII within Nukhul Formation in Rabeh East-8 Well<smiles></smiles> 


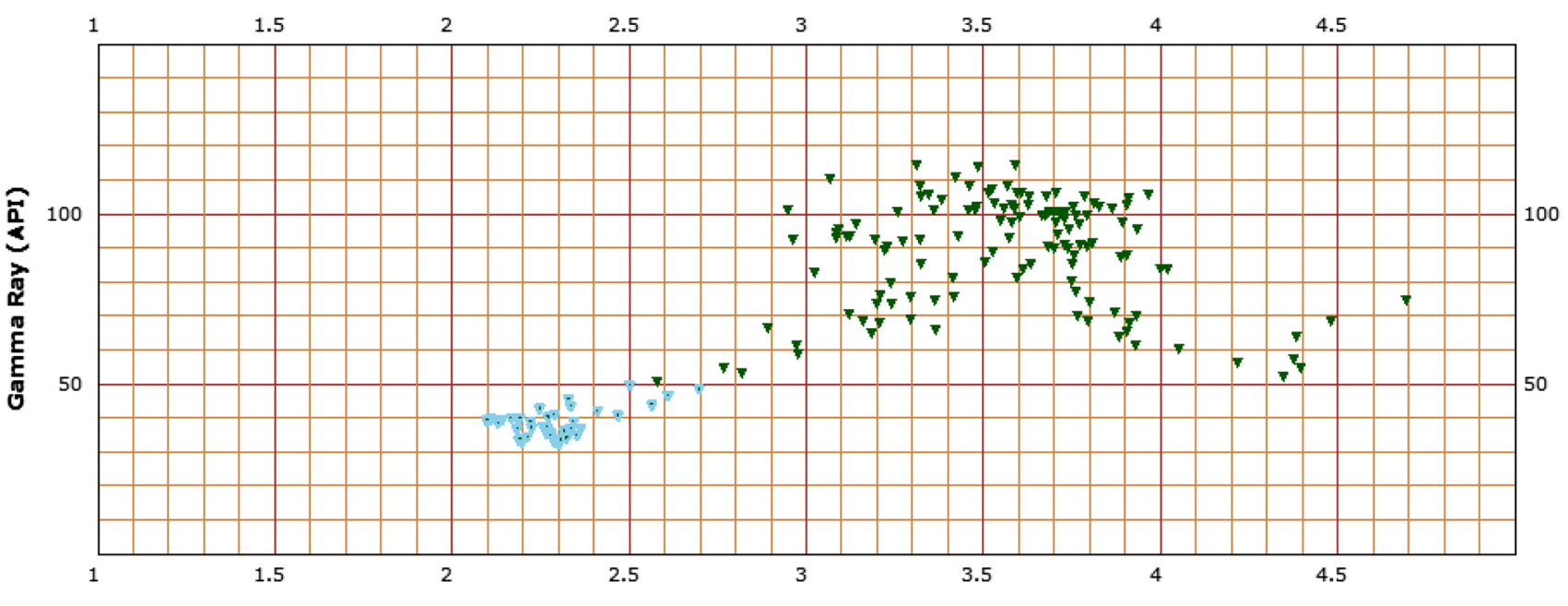

Photoelectric (B/E)

Fig. 8 Gamma ray-photoelectric plot for Nukhul Formation in Rabeh East-8 Well. Note: Points highlighted by blue colour represent zone I and zone II with low gamma ray values reflecting the clean nature of their entire sandstones (i.e. low shale content)

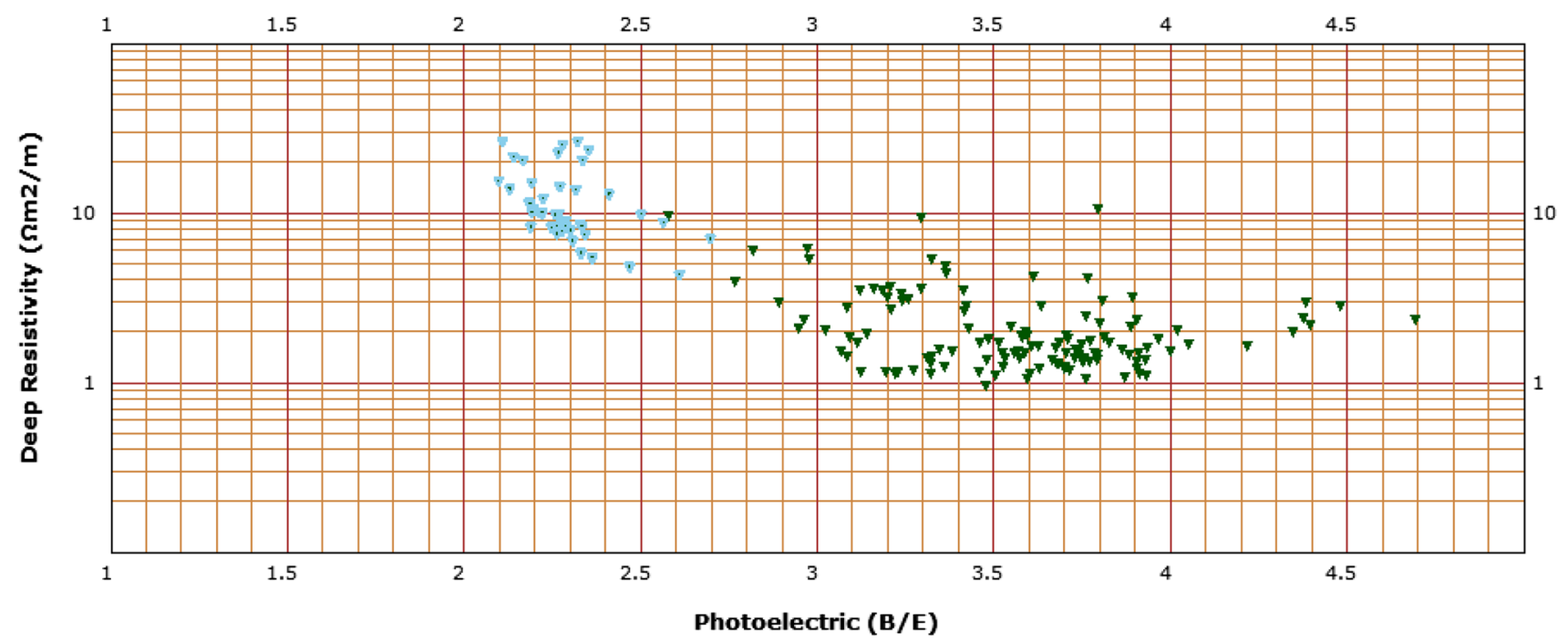

Fig. 9 Deep resistivity-photoelectric plot for Nukhul Formation in Rabeh East-8 Well. Note: Points highlighted by blue colour represent zone I and zone II with high deep resistivity values reflecting the presence of hydrocarbon in these zones

zones equals only $9.9 \%$, confirming that zone I and zone II are oil-bearing zones of high quality.

\section{Conclusions}

The detailed petrophysical analysis for the sandstones of Nukhul Formation in RE-8 Well at Rabeh East oil field revealed that the zones locate between depths 5411.5 and $5424 \mathrm{ft}(12.5 \mathrm{ft}$ thick $)$ and between 5451 and $5459.5 \mathrm{ft}(8.5$ ft thick) have very good reservoir characteristics for oil production. These characteristics including the high total porosity (18-24\%) and high effective porosity (11-20\%) in addition to the low water saturation (13-45\%), low shale volume (10-30\%) and low bulk volume of water (0.03-0.06).

The available production data confirm the present analysis reflecting the excellent petrophysical parameters for the sandstones of Nukhul Formation in Rabeh East oil field. But this depends on whether the location of the drilled well penetrates a suitable structural closure (structural highs) or not. 


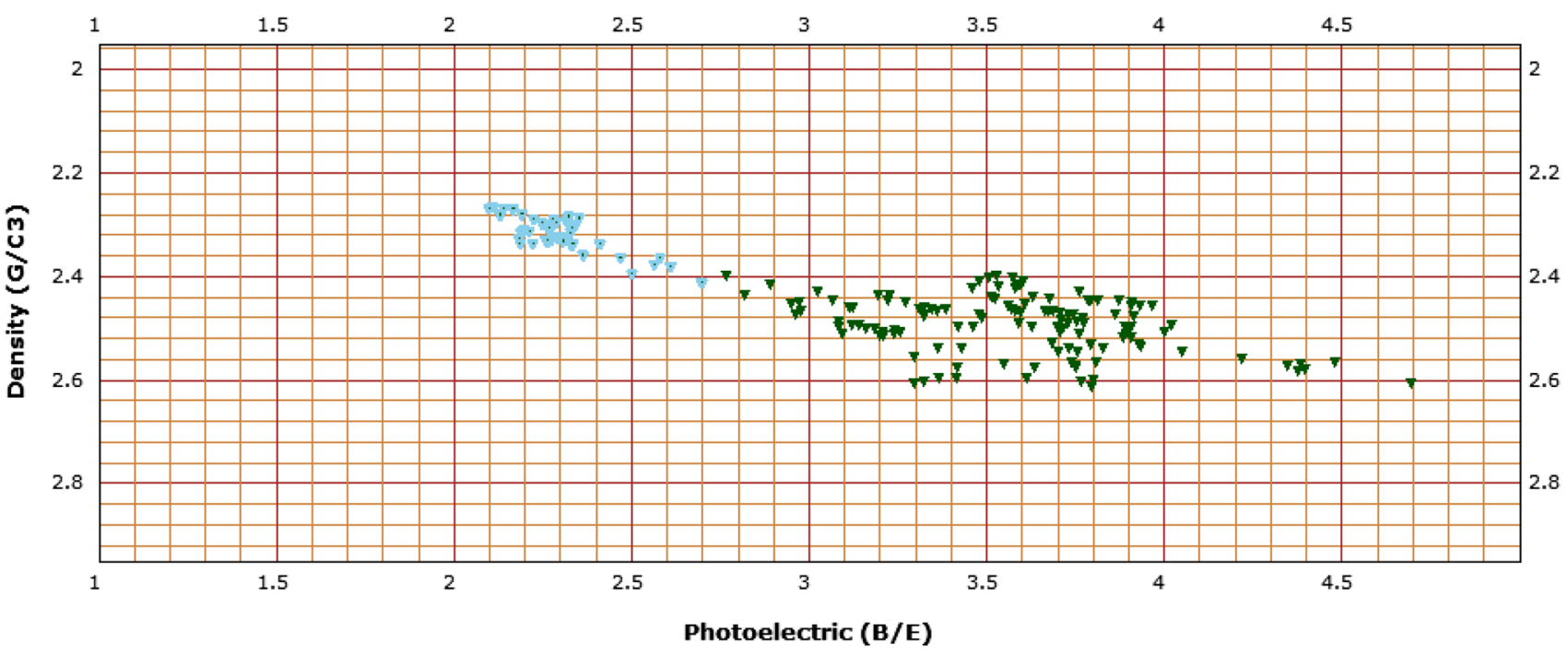

Fig. 10 Density-photoelectric plot for Nukhul Formation in Rabeh East-8 Well. Note: Points highlighted by blue colour represent zone I and zone II with low density values reflecting the presence of porosity and oil in these pzones

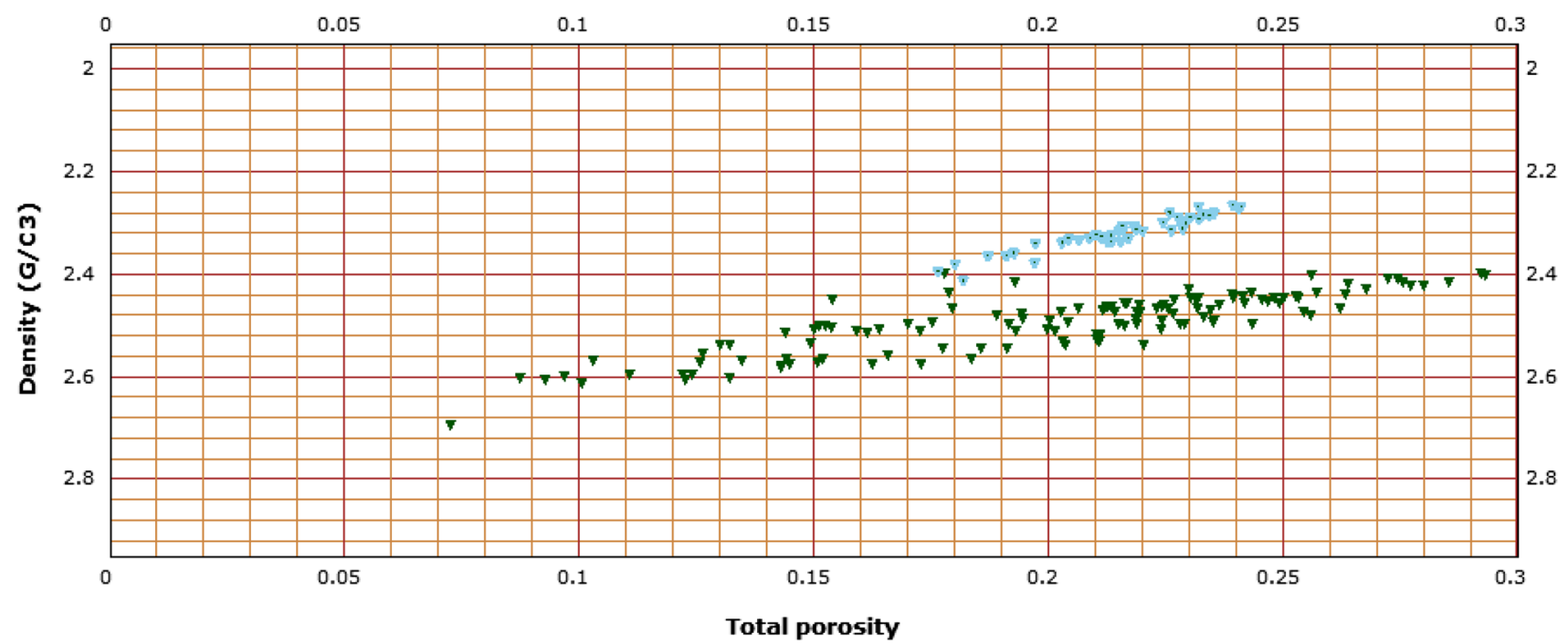

Fig. 11 Density-total porosity plot for Nukhul Formation in Rabeh East-8 Well. Note: Points highlighted by blue colour represent zone I and zone II with low density and high porosity values reflecting the promising nature for the examined zones 


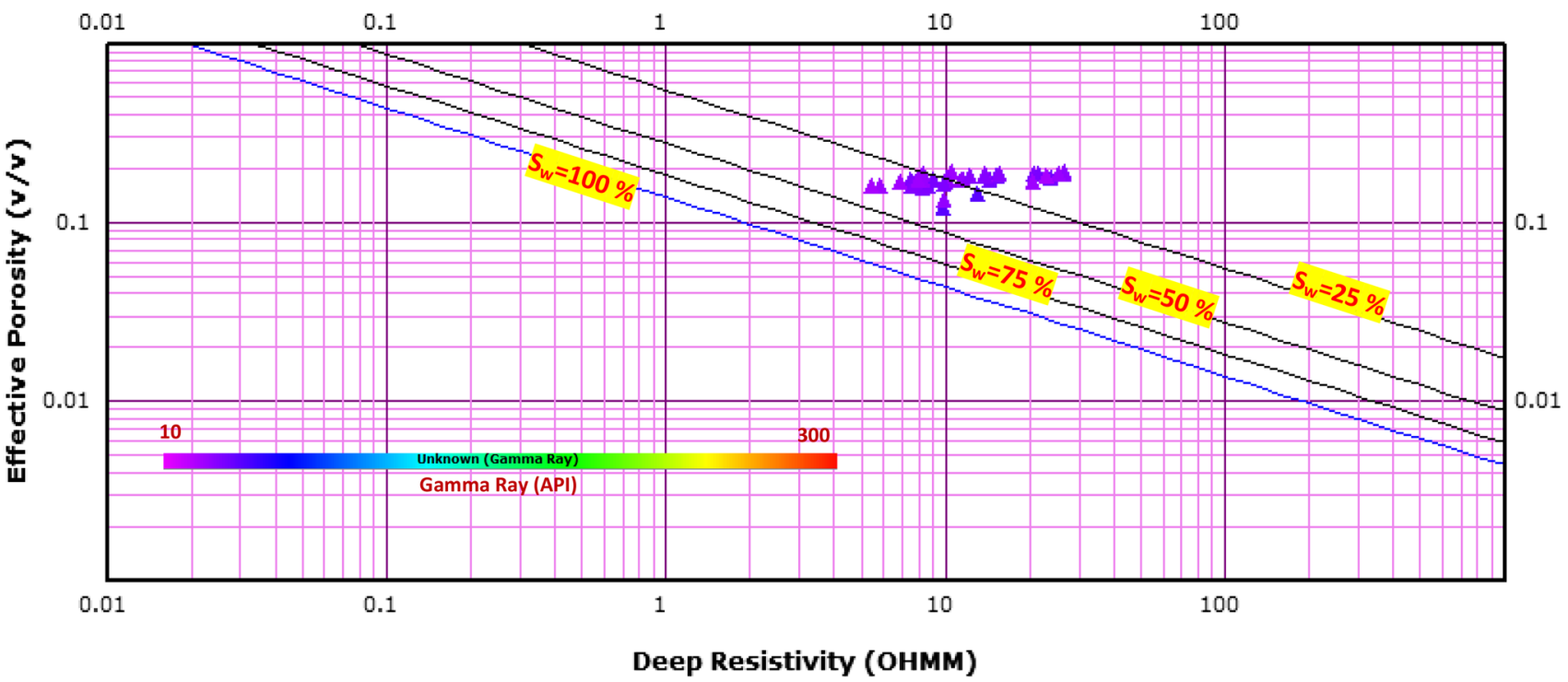

Fig. 12 Pickett plot for zone 1 and zone II within Nukhul Formation in Rabeh East- 8 Well. Note that the all points locate less than $S_{\mathrm{w}}=50 \%$ line representing the hydrocarbon potentiality of both zones

Acknowledgements Many thanks to Ganoub El-Wadi Petroleum Holding Company and Egyptian General Petroleum Corporation (EGPC) for providing the data existing in this article.

Funding No fund has been provided through this work. Accordingly, there is no fundingstatement.

\section{Declarations}

Conflict of interest Here I confirm that there is no conflict of interest and I hope my paper will have a quick process and getting published in Journal of Petroleum Exploration and Production Technology.

Ethical approval Hereby, I consciously assure that this manuscript has not been previously published elsewhere and the paper is not currently being considered for publication elsewhere. Also, the paper reflects my own research and analysis in a truthful and complete manner. And the results are appropriately placed in the context of prior and existing research. Also, all sources used are properly disclosed (in correct citation).

Open Access This article is licensed under a Creative Commons Attribution 4.0 International License, which permits use, sharing, adaptation, distribution and reproduction in any medium or format, as long as you give appropriate credit to the original author(s) and the source, provide a link to the Creative Commons licence, and indicate if changes were made. The images or other third party material in this article are included in the article's Creative Commons licence, unless indicated otherwise in a credit line to the material. If material is not included in the article's Creative Commons licence and your intended use is not permitted by statutory regulation or exceeds the permitted use, you will need to obtain permission directly from the copyright holder. To view a copy of this licence, visit http://creativecommons.org/licenses/by/4.0/.

\section{References}

Abd El Gawad E, Abd El Hafez N, Hammed MS, El Naggar HA (2016) Characterization of pre-rift reservoirs of western Hurghada district, Egypt. Int J of Innov Sci Eng Technol 3(12):74-83

Abd El Hafez N, Abd El Gawad E, Hammed MS, El Naggar HA (2016) Subsurface structural imaging and architecture of pre-rift sediments of west Hurghada district Egypt. Int J Innov Sci, Eng Technol 3(12):84-98

Abd-Allah AM, Aal MHA, El-Said MM, El-Naby AA (2014) Structural evolution of the southern transfer zone of the Gulf of Suez rift Egypt. J Afr Earth Sci 96:21-38

Abul Karamat S, and Meshref W (2002) Reverse fault geometry in the Gulf of Suez Rift Basin, Egypt. In: International petroleum conference and exhibition. pp. 27-30

Alsharhan AS (2003) Petroleum geology and potential hydrocarbon plays in the Gulf of Suez rift basin Egypt. AAPG Bull 87(1):143-180

Asquith GB (1985) Handbook of log evaluation techniques for carbonate reservoirs. Methods in exploration series, Member 5, AAPG, Oklahoma, USA

Asquith G, Gibson C (1982) Basic well log analysis for geologists: methods in exploration series. AAPG, Tulsa

Bosworth W, Huchon P, McClay K (2005) The red sea and gulf of aden basins. J Afr Earth Sci 43(1-3):334-378

Bosworth W, McClay KR (2001) Structural and stratigraphic evolution of the Gulf of Suez rift, Egypt: a synthesis. Mémoires Du Muséum National D'histoire Naturelle 1993(186):567-606

Buckles RS (1965) Correlating and averaging connate water saturation data. J Can Pet Technol 4(1):42-52

Chowdhary LR, Taha S (1987) Geology and habitat of oil in Ras Budran field, Gulf of Suez. Egypt AAPG Bull 71(10):1274-1293

El Nady MM, Mohamed NS, Shahin AN (2016) Source-rock potential of Miocene-Paleozeoic sediments in GH-376 oilfield, South Gulf of Suez Egypt. En Sour, Part A: Recover, Util, Environ Eff 38(1):100-109

El Nady MM, Ramadan FS, Hammad MM, Lotfy NM (2015) Evaluation of organic matters, hydrocarbon potential and thermal

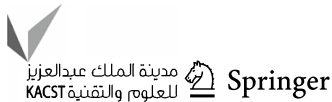


maturity of source rocks based on geochemical and statistical methods: case study of source rocks in Ras Gharib oilfield, central Gulf of Suez Egypt. Egypt J Pet 24(2):203-211

Fertl WH, and Vercellino WC (1978) Predict water cut from well logs, in practical log analysis, Part 4: Oil and Gas Journal, (May 15, 1978-Sept. 19, 1979)

McClay KR, Nichols GJ, Khalil SM, Darwish M, and Bosworth W (1998). Extensional tectonics and sedimentation, eastern Gulf of Suez, Egypt. In Sedimentation and tectonics in Rift Basins Red Sea: Gulf of Aden (pp. 223-238). Springer, Dordrecht

Moustafa AR, Khalil SM (2020) Structural setting and tectonic evolution of the Gulf of Suez, NW red sea and Gulf of Aqaba Rift systems. In: Hamimi Z, El-Barkooky A, Frías JM, Fritz H, ElRahman YA (eds) The geology of Egypt. Springer, Cham, pp 295-342

Patton TL, Moustafa AR, Nelson RA, Abdine SA (1994) Tectonic evolution and structural setting of the Suez rift. In: Landon, SM (Ed.), Interior rift basins. American Association of Petroleum Geologists Memoir 59: pp. 9-55

Peijs JAMM, Bevan TG, Piombino JT (2012) The Gulf of Suez rift basin. In: Roberts, Bally (Eds.), Phanerozoic rift systems and sedimentary basins. Elsevier B.V., pp. 165-194

Pickett GR (1972) Practical formation evaluation. Pickett Inc Golden, Colorado, G.R

Poupon A, and Leveaux J (1971) Evaluation of water saturation in shaly formations. In: SPWLA 12th annual logging symposium. Society of Petrophysicists and Well-Log Analystś

Radwan AE (2021) Modeling pore pressure and fracture pressure using integrated well logging, drilling based interpretations and reservoir data in the giant El Morgan oil field, Gulf of Suez Egypt. J Afr Earth Sci 178:104165

Radwan AE (2021b) Modeling the depositional environment of the sandstone reservoir in the middle miocene sidri member, badri field, Gulf of Suez Basin, Egypt: integration of gamma-ray $\log$ patterns and petrographic characteristics of lithology. Nat Resour Res 30(1):431-449

Radwan AE, Abdelghany WK, Elkhawaga MA (2021) Presentday in-situ stresses in Southern Gulf of Suez, Egypt: insights for stress rotation in an extensional rift basin. J Struct Geol 147:104334

Radwan AE, Kassem AA, Kassem A (2020) Radwany Formation: a new formation name for the early-middle eocene carbonate sediments of the offshore october oil field, Gulf of Suez: contribution to the eocene sediments in Egypt. Mar Petrol Geol 116:104304

Radwan AE, Rohais S, Chiarella D (2021) Combined stratigraphicstructural play characterization in hydrocarbon exploration: a case study of middle miocene sandstones, Gulf of Suez basin, Egypt. J Asian Earth Sci. https://doi.org/10.1016/j.jseaes.2021.104686

Radwan AE, Trippetta F, Kassem AA, Kania M (2021) Multi-scale characterization of unconventional tight carbonate reservoir: Insights from october oil filed, Gulf of Suez rift basin Egypt. J Petrol Sci Eng 197:107968

Radwan A, Sen S (2021) Stress path analysis for characterization of in situ stress state and effect of reservoir depletion on present-day stress magnitudes: reservoir geomechanical modeling in the Gulf of Suez Rift Basin Egypt. Nat Resour Res 30(1):463-478

Saoudi A, and Khalil B (1984 Distribution and hydrocarbon potential of Nukhul sediments in the Gulf of Suez. In: Proceedings of 7th petroleum exploration and production conference. pp. 75-96

Sarhan MA (2020) Geophysical appraisal and oil potential for Rudeis Formation at West Hurghada area, southern Gulf of Suez: detection of stratigraphic trap. Arab J Geosci 13(6):1-9

Sarhan MA, Basal AMK (2019) Evaluation of Nubia sandstone reservoir as inferred from well logging data interpretation for Rabeh East-25 well, Southwest Gulf of suez Egypt. J Afr Earth Sci 155:124-136

Sarhan MA, Collier REL, Basal A, Aal MHA (2014) Late Miocene normal faulting beneath the northern Nile Delta: NNW propagation of the Gulf of Suez Rift. Arab J Geosci 7(11):4563-4571

Schlumberger (1972) Log interpretation/charts. Schlumberger Well Services Inc, Houston

Schlumberger (1995). Well evaluation conference, Egypt. Paris, France, p. 87

Schutz KI (1994) Structure and stratigraphy of the Gulf of Suez, Egypt: Chapter 2: Part I. Type Basin: Gulf of Suez

Sultan N (2002) Gulf of Suez/Red Sea structural evaluation and hydrocarbon potentiality. In: International petroleum conference and exhibit. p. 82

Temraz M, Dypvik H (2018) The lower miocene Nukhul Formation (Gulf of Suez, Egypt): microfacies and reservoir characteristics. J Petrol Explor Prod Technol 8(1):85-98

Winn RD Jr, Crevello PD, Bosworth W (2001) Lower miocene Nukhul Formation, Gebel el Zeit, Egypt: model for structural control on early synrift strata and reservoirs Gulf of Suez. AAPG Bulletin 85(10):1871-1890

Publisher's Note Springer Nature remains neutral with regard to jurisdictional claims in published maps and institutional affiliations. 